\title{
Early Medieval ceramics from the Viile Tecii archaeological site (Romania): an optical and XRD study
}

\author{
Corina IONESCU ${ }^{1}$, Lucreția GHERGARI ${ }^{1}$, Marius HORGA ${ }^{2}$ \\ Gabriela RĂDULESCU ${ }^{2}$
}

${ }^{1}$ Department of Mineralogy, „Babeş-Bolyai“ University, Kogălniceanu 1, 400084 Cluj Napoca, Romania

${ }^{2}$ Bistrița-Năsăud County Museum, General Grigore Bălan 19, 420016 Bistrița, Romania.

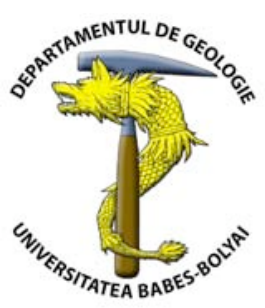

\begin{abstract}
Mineralogical and petrographic studies of Early Medieval potshards exhumed in the Viile Tecii archaeological site (North Transylvania, Romania) show a ceramic body composed of a microcrystalline to amorphous matrix, various clasts and voids. The microscopical features and XRD patterns indicate that illitickaolinitic clays were used as raw materials, together with quartzitic sands as tempering material. The ceramic vessels were obtained with the potter's wheel, but the fabric is only slightly oriented, due either to the fast modeling or to the coarseness of the clayish paste. The thermal alteration of mineral phases points to relatively high firing-temperatures, between 800 and $900^{\circ} \mathrm{C}$.
\end{abstract}

Key words: Archaeological ceramics, Early Medieval age, Raw materials, Thermal changes, Transylvania, Romania.

\section{INTRODUCTION AND ARCHAEOLOGICAL DATA}

Apart from the works by Ghergari et al. $(2005,2006)$, the mineralogical and petrographic studies on medieval ceramics are rare in Romania. The present paper represents the first study of the potshards found by the archaeologist Gabriela Rădulescu on the Cetătiii Hill (Fortress Hill) near the Viile Tecii village (Fig. 1), located south of the city of Bistrița. The Cetății Hill was used for fortifications in different periods, starting with prehistoric times till medieval ages.

The systematic archaeological investigations unveiled the following overlapping levels (from bottom to top): a prehistoric level, a Dacian fortification, a Roman tower and post-Roman complexes.

Around the beginning of the second millennium an Early Medieval fortification was built; it had earthen-walls and was surrounded with a wooden palisade. The last fortification phase with stone walls took place in the XIVXVI centuries.

In the course of the archaeological research, mainly ceramic remnants such as potshards or vessels were exhumed from all levels. The investigated potshards were found inside the walls of the Early Medieval fortress (end of the first millennium-beginning of the second millennium).

The research and dating of the archaeological material of Early Medieval age is relatively difficult due to the spreading of similar artifacts on large areas (Stanciu, 1994). As the ceramic shards represent the main part of the archaeological findings, their detailed study is important for identifying any common and/or distinctive features.

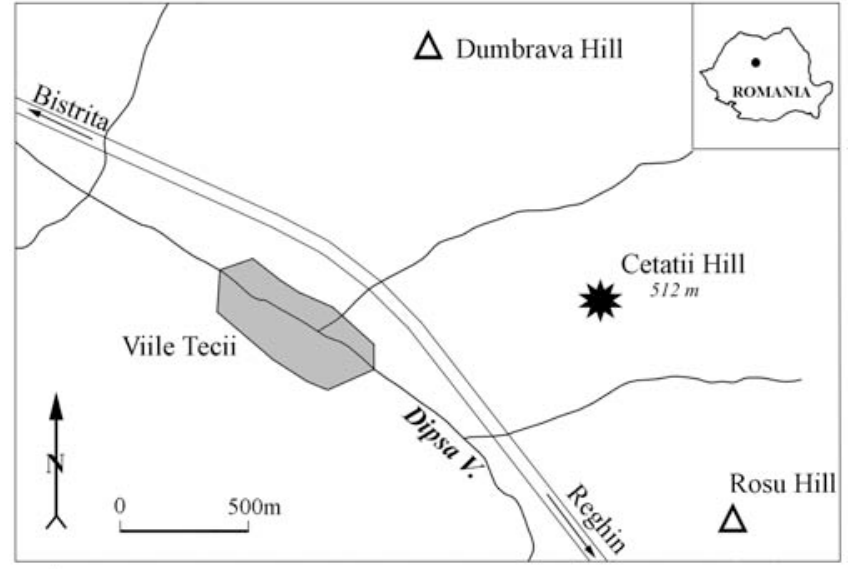

Viile Tecii archaeological site

Fig. 1. The location of the Viile Tecii archaeological site.

\section{SAMPLES AND METHODS}

Three potshards, labeled from 270 to 272 were used for the present study. From each shard, two slices were cut across the ceramic wall, in order to prepare thin sections for the mineralogical and petrographic studies in polarized light. Optical microscopy (OM) was performed with Nikon Eclipse E200 Pol microscope and images were captured with a digital Coolpix 995 Nikon camera.

Few grams from each ceramic fragment were milled in an agate mortar and measured by X-Ray powder diffraction (XRD), at room temperature, with a Dron-3 diffractometer operating at $20 \mathrm{kV}$ and $20 \mathrm{~mA}$, at a scan speed of $2^{\circ} \theta / \mathrm{min}$, from 2 to $64^{\circ} 2 \theta$, using $\mathrm{CuK}_{\alpha 1}$ radiation with $\lambda=1.54051 \AA$. 
For the sample 270, the XRD analysis was made after removing a thin white painting covering the surface.

The study of the ceramic fragments focused on thermal changes in order to infer the firing temperatures.

\section{MACROSCOPICAL AND MICROSCOPICAL FEATURES OF CERAMICS}

Macroscopically, the samples have different colors. The potshard $270(6.6 \times 3.8 \mathrm{~cm} ; 1.1 \mathrm{~cm}$ thickness of the ceramic wall) shows a homogeneous reddish-brown color. The surface is covered with a white paint. The sample 271 (4.7 $\mathrm{X}$ $2.5 \mathrm{~cm} ; 0.6 \mathrm{~cm}$ thickness) has a slight "sandwich structure" with grayish core grading into light brown zones towards the margins. The sample $272(4.4 \times 3.3 \mathrm{~cm} ; 0.9 \mathrm{~cm}$ thickness $)$ displays a more clear "sandwich structure", i.e. a grayishbrown core and distinct red layers at the margins. The red layers reach $1 \mathrm{~mm}$ in thickness. Various inclusions, easily seen with a magnifying lens, were identified as quartzitic sands used as temper ${ }^{1}$. The samples 270 and 271 have a higher porosity compared with sample 272 and elongated pores and cracks as well as holes around some large clasts are quite common.

\section{Ceramic fineness}

The granulometric characteristics of the potshards were obtained by planimetric measurements in thin sections, taking into account previous studies regarding the granulometric classification of ceramics (Ghergari et al., 1999; Ionescu and Ghergari, 2002, 2004). This classification establishes a $15 \%$ content of arenite (particles larger than $0.063 \mathrm{~mm}$ ) as the limit betweeen coarse and semi-fine ceramics. The samples 270 and 271 classify as coarse ceramics, having 20 and $17 \%$ arenite, respectivelly. The sample 272 is semi-fine with $10 \%$ arenite.

\section{Mineralogy and petrography}

Microscopically, the ceramic body is composed of matrix, clasts and voids. The matrix is a clayish mass transformed upon firing (Pl. I-II, Figs. 1-8). Depending of the intensity of the thermal changes, the matrix is either microcrystalline (e.g. Pl. I-II, Figs. 1-5) or amorphous (e.g., P1. II, Fig. 6). The samples 270 and 272 show a highly birefringent, microcrystalline matrix, typical for illitic clays. Thin layers of an amorphous isotropic phase surround the clay particles and reflect the sintering process. The sample 271 has an isotropic matrix composed of glass mixed with an amorphous phase i.e. clay minerals with collapsed structures. The matrix of the sample 271 has most likely a kaolinitic composition (metakaolinite). When viewed in plane polarized light, all the samples show a brownish-red translucent to opaque matrix, probably due to Fe content.

The clasts $^{2}$ (Pl. I-II, Figs. 1-8) are fragments of rocks (lithoclasts), individual crystals (crystalloclasts) or older potshards (ceramoclasts). The quantity and type of lithoclasts are different for each sample, but in all, quartzitic lithoclasts and quartz crystalloclasts are prevalent. Fragments of gneisses and micaschists are also present. The

\footnotetext{
${ }^{1}$ Usually sands, potshards or vegetals were intentionally added by the potter in order to control the plasticity and workability of the ceramic paste.

${ }^{2}$ Few clasts originate from the clayish raw materials but most of them represent temper material.
}

magmatic rocks identified in the shards are granites, granodiorites and andesites. Sandstones, limestones, silts, chalcedony are the most common sediments. Ferruginous concretions of soil origin are rare (Pl. I, Fig. 3).

The crystalloclasts are represented by quartz, feldspars (plagioclase, microcline and orthoclase), micas (muscovite and biotite) and rare fragments of garnet, titanite, zircon, apatite, opaque minerals and calcite. The ceramoclasts are very scarce and were incidentally incorporated in the paste.

The arrangement of the matrix components and clasts inside the ceramic body shows a slight preferential lineation, more or less parallel with the ceramic wall surface. However, relatively large clasts may crosscut the lineation, as seen in Pl. I, Fig. 3 and 4. The microfabric is generally isotropic, not oriented. Occasionally, some elements such as pores or micas display a planar arrangement, parallel to the ceramic wall surface.

The porosity - as seen under the microscope - is represented mainly by elongated voids. Partly, these voids are primary pores, randomly distributed in the ceramic body. They resulted during the modeling process, when thin films of water and/or air were trapped between clay layers. Later, upon drying and firing, the primary pores size has increased. Besides the primary pores, numerous secondary voids arranged in planes more or less parallel to the ceramic wall surface are observed. The secondary pores have either an irregular shape - when formed through the decomposition of certain components (as carbonates), or an elongated shape, similar to that of the primary pores - when formed through drying and shrinkage processes that accompanied the firing (Shepard, 1976; Maggetti, 1982; Velde and Druc, 1999). The contraction voids surrounding large clasts, represent also secondary pores.

\section{X-RAY DIFFRACTOMETRY}

The diffractograms obtained for powdered samples (Fig. 2) show the presence of thermally-unchanged minerals, such as quartz, feldspars, micas, calcite.

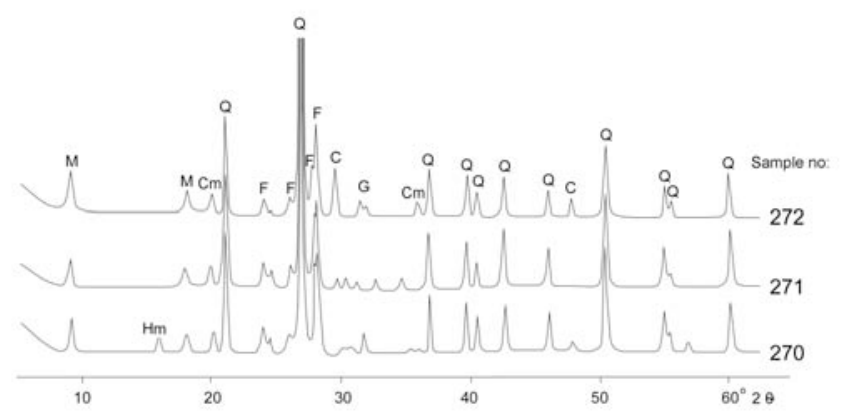

Fig. 2. X-Ray diffractograms of the Viile Tecii potshards: $Q$ for quartz, $C$ for calcite, $M$ for micas, Cm for clay minerals, $F$ for feldspar, $G$ for gehlenite, Hm for hydromagnesite.

Due to the partial collapse of the crystalline structure of clay minerals - most likely illite, only the 4.5, 2.5 and $2.6 \AA$ lines have been identified. Additionally, the intensity of the $4.5 \AA$ line (illite, montmorillonite, micas) is diminished. The $7 \AA$ line of kaolinite is missing in all samples. The newlyformed minerals (firing-minerals) as identified by XRD lines are gehlenite (samples 270 and 272) and probably part of feldspars (all samples). Only the sample 270 shows burial-specific minerals such as hydromagnesite. 


\section{THERMAL TRANSFORMATION UPON FIRING AND DISSCUSIONS}

The optical microscopy and XRD allowed the identification of several thermal processes, which affected mainly the clayish matrix. Among these, the most important are the following:

- Slight sintering processes in the clayish matrix of samples 270 and 272;

- Formation of isotropic, amorphous and/or glassy areas in the matrix (sample 271; see P1. II, Fig. 6);

- Advanced fissuring of quartz clasts in sample 270 due to thermal shock (Pl. II, Fig. 5);

- Slight decomposition of calcitic clasts rims in sample 272 (P1. II, Fig. 7);

- Developing of contraction voids around large clasts, later invaded by melt (sample 270; see Pl. II, Fig. 8);

- Developing of secondary pores in all samples;

- Partial decomposition of micas (samples 270 and 272; Pl. III, Fig. 9);

- Reaction zones between quartz clasts and matrix, sometimes with the diffusion of Fe from matrix into the clast (sample 271; see P1. III, Fig. 10);

- Melting of quartz rims of and formation of a scalloped texture (sample 271; see Pl. III, Fig. 10);

- Forming of gehlenite in samples 270 and 272, as recognized by XRD (Fig. 2);

- Diminishing of the $4.5 \AA$ line of clay minerals in XRD (Fig. 2);

- Lack of the $7 \AA$ line of kaolinite in the XRD of all samples (Fig. 2).

By comparing these observations with various reference data (Shepard, 1976; Maggetti, 1982; Duminuco et al., 1998; Gualtieri and Venturelli, 1999; Cairo et al., 2001; Antonelli et al., 2002; Kacim and Hajjaji, 2003; Broeckmans et al. 2004; Maritan, 2004; Cultrone et al., 2005 and references herein) and with our own experimental data obtained for clays from Transylvania (Romanian Ministry of Education, Grant 1762), the firing temperatures for the ceramics could be inferred.

Samples 270 and 272 show sintering processes limited strictly to the contact between the particles and indicating at least $600^{\circ} \mathrm{C}$. Sample 271 has an amorphous matrix, with more frequent melting and amorphisation processes, thus indicating temperatures over $750^{\circ} \mathrm{C}$ (acc. to Broeckmans et al. 2004) but below $850^{\circ} \mathrm{C}$. Over $850-900^{\circ} \mathrm{C}$ the melting of matrix components is already common. Micas start to decompose around $800^{\circ} \mathrm{C}$ and the partial decomposition and changes of birefringence as noticed in sample 270 and 272 suggests firing around $850^{\circ} \mathrm{C}$.

The forming of gehlenite in samples 270 and 272 points to temperature above $800-850{ }^{\circ} \mathrm{C}$ (Riccardi et al., 1999) but the presence of not-transformed or only marginallydecomposed inclusions, such as calcite grains or limestone clasts within the same sample 272 (Pl. II, Fig. 7), suggests firing temperatures below $850^{\circ} \mathrm{C}$ (acc. to Cultrone et al., 2001). Nemecz (1973) showed that certain diffraction lines of clay minerals such as illite and montmorillonite tend to diminish starting with $750-800^{\circ} \mathrm{C}$, as can be seen as well as in all diffractograms (Fig. 2). The lack of kaolinite lines in all samples does not indicate that this mineral was originally missing in the raw materials but suggests temperatures much above $600-650^{\circ} \mathrm{C}$ when the crystalline structure collapses and metakaolinite forms.

\section{CONCLUSIONS}

The results of the mineralogical and petrographic study of the Early Medieval potshards found in the Viile Tecii settlement (Transylvania, Romania) can be summarized as follows:

1. The ceramics was obtained most likely from a mixture of common illitic-kaolinitic clays; quartzitic sands were added as temper.

2. The raw materials used for all investigated samples, obviously contained $\mathrm{Fe}$ oxides and hydroxides. $\mathrm{Fe}^{2+}$ was oxidized to $\mathrm{Fe}^{3+}$ at higher temperature and remained trapped as tiny particles into glass and an amorphous phase.

2. The raw materials used for sample 272 contained a relatively high amount of calcite, preserved upon the firing due to a temperature below decomposition point $\left(900{ }^{\circ} \mathrm{C}\right)$.

3. The three samples come from different kiln loads: the sample 270 was fired in a constant oxidizing atmosphere, around $800-850^{\circ} \mathrm{C}$. The sample 271 was fired at higher temperature, around $850-900{ }^{\circ} \mathrm{C}$, but in a constant, reducing atmosphere. Only close to the end of firing some oxygen could enter into the kiln. The sample 272 was fired at the same temperature as sample 270 but it recorded a variable atmosphere, from a reducing to an oxydizing one. The thick red surfaces of the ceramic wall for the potshard 272 indicate that the firing continued after the opening of the kiln, probably to give to the wares an attractive brick-red colour.

4. The petrographic and mineralogical features of the potshards, i.e. clasts and matrix, compare well with the neighbouring geological formations such as Badenian illitickaolinitic clays and Dipşa river alluvial sands (Geological map of Romania, 1967), thus suggesting a local production source.

Acknowledgements. The research was supported by the Romanian Ministry of Education (Grant 1762). The manuscript benefited from the careful reviews by Gh. Ilinca, D. Hovorka, and V. Hoeck. Special thanks go to M. Mereu for computer-assisted drawings.

\section{R E F E R E N C E S}

Antonelli, F., Cancelliere, S. \& Lazzarini, L. 2002, Mineropetrographic characterisation of historic bricks in the Arsenale, Venice. Journal of Cultural Heritage, 3: 59-64.

Broeckmans, T., Adriaens, A. \& Pantos, E., 2004, Analytical investigations of cooking pottery from Tell Beydar (NE-Syria). Nuclear Instruments and Methods in Physics Research, B 226: 92-97.

Cairo, A., Messiga, B. \& Riccardi, M.P., 2001, Technological features of the "Cotto Variegato": a petrological approach. Journal of Cultural Heritage, 2: 133-142.

Cultrone, G., Rodriguez-Navarro, C., Sebastian, E., Cazalla, O. \& De la Torre, M.J., 2001, Carbonate and silicate phase reactions during ceramic firing. European Journal of Mineralogy, 13: 621-634.

Cultrone, G., Sebastián, E. \& De la Torre, M.J., 2005, Mineralogical and physical behaviour of solid bricks with additives. Construction \& Building Materials, 19: $39-48$. 
Duminuco, P., Messiga, B., \& Riccardi, M.P., 1998, Firing process of natural clays. Some microtextures and related phase compositions. Thermochimica Acta, 321: 185-190.

Ghergari, L., Lazarovici, Gh., Ionescu, C. \& Tămaş, T., 1999, Geoarchaeological studies on ceramic artifacts from Early Neolithic from Romania: Lunca-Poiana Slatinii, Neamț county (in Romanian). Angvstia, 4: 1-7.

Ghergari, L., Ionescu, C., Horga, M. \& Rădulescu, G., 2005, Mineralogical-petrographic studies of Early Medieval pottery from Ş ieu-Odorhei (Bistrița-Năsăud County, Romania) (In Romanian). Arheologia medievală, V: 171-190.

Ghergari, L., Ionescu, C., Hoeck, V., Lazăr, C. \& Precup, C., 2006, Archaeoceramics from Oradea Fortress: a mineralogocal study. Anuarul Institutului Geologic al României, 74 (1): 71-74.

Gualtieri, A.F., Venturelli, P., 1999, In situ study of goethite-hematite phase transformation by real time synchroton powder diffraction. American Mineralogist, 84: 895-904.

Ionescu, C., Ghergari, L., 2002, Modeling and firing technology - reflected in the textural features and mineralogy of the ceramics from Neolithic sites in Transylvania (Romania). Geologica Carpathica, 53 (www.geologicacarpathica.sk/special///Ionescu_Ghergari.pdf).

Ionescu, C., Ghergari, L., 2004, Vinča ceramics (Middle Neolithic) in Transylvania: petrographical and geoarchaeological features. In The Proceedings of The $5^{\text {th }}$ International Symposium on Eastern Mediterranean Geology (Chatzipetros, A.A., Pavlides, S.B., Eds.), 2: 751-754, Thessaloniki.
Kacim, S., Hajjaji, M., 2003, Firing transformations of a carbonatic clay from the High-Atlas, Morocco. Clay Minerals, 38: 361-365.

Maggetti, M., 1982, Phase analysis and its significance for technology and origin. In Archaeological ceramics (Olin, J.S., Franklin, A.D., Eds.), Smithsonian Institute Press, p. 121-133.

Maritan, L., 2004, Archaeometric study of Etruscan-Padan type pottery from the Veneto region: petrographic, mineralogical and geochemical-physical characterrization. European Journal of Mineralogy, 16: 297-307.

Nemecz, E., 1973, Clay minerals (in Hungarian). Akademiai Kiadó Budapest, 507 p.

Riccardi, M.P., Messiga, B. \& Duminuco, P., 1999, An approach to the dynamics of clay firing. Applied Clay Science, 15: 393-409.

Shepard, O.A., 1976, Ceramics for the archaeologist. Carnegie Institute Washington, $414 \mathrm{p}$.

Stanciu, I., 1994, Prefeudal settlement from Lăpuşel, Maramueş County, Romania. 1992-1993 archaeological research (in Romanian). Ephemeris Napocensis, IV: 267-332.

Velde, B., Druc, C.I., 1999, Archaeological ceramic materials. Origin and utilization. Springer-Verlag Berlin, 299 p.

Geological Map of Romania, 1967, 1:200.000, Bistrița Sheet, Geological Institute of Romania, Bucharest. 


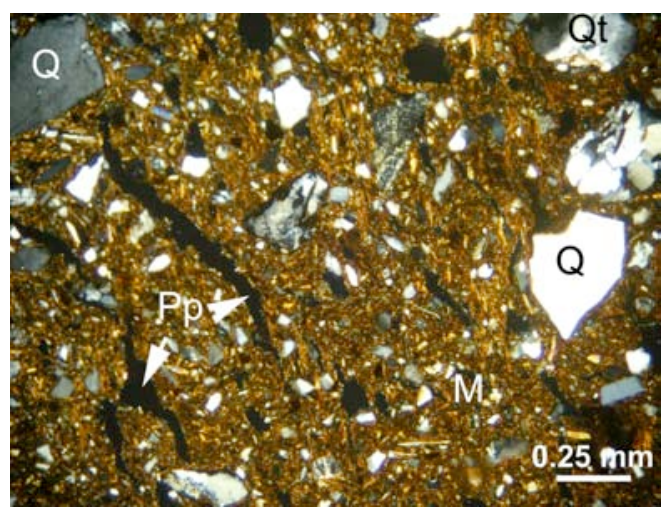

PLATE I

Fig. 1. Coarse ceramics, sample 270. Microcrystalline, anisotropic matrix (M), with quartzite lithoclasts (Qt) and crystalloclasts (feldspar, mica, quartz-Q). Pp for primary pores. $\mathrm{N}+$

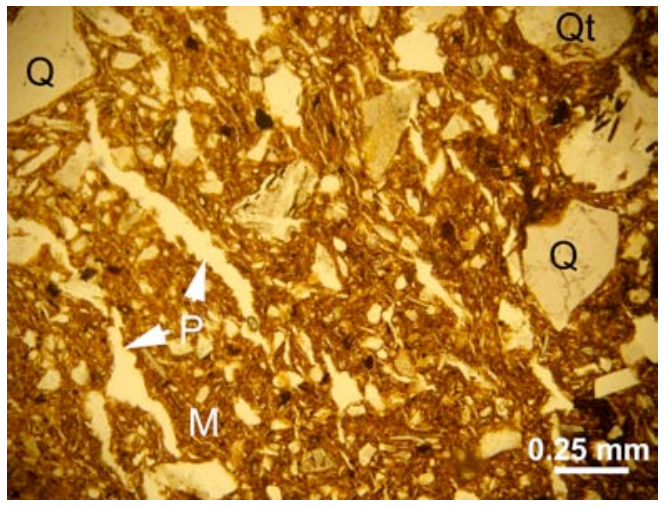

Fig. 2. Same as Fig. 1, $1 N$

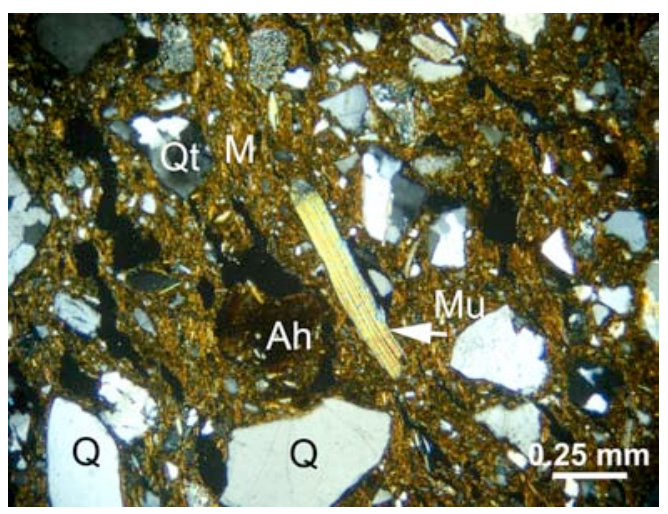

Fig. 3. Coarse ceramics, sample 270. Microcrystalline, anisotropic matrix (M), and quartzite (Qt), quartz $(Q)$ and muscovite $(\mathrm{Mu})$. Ah for hematitic soil aggregate. $N+$

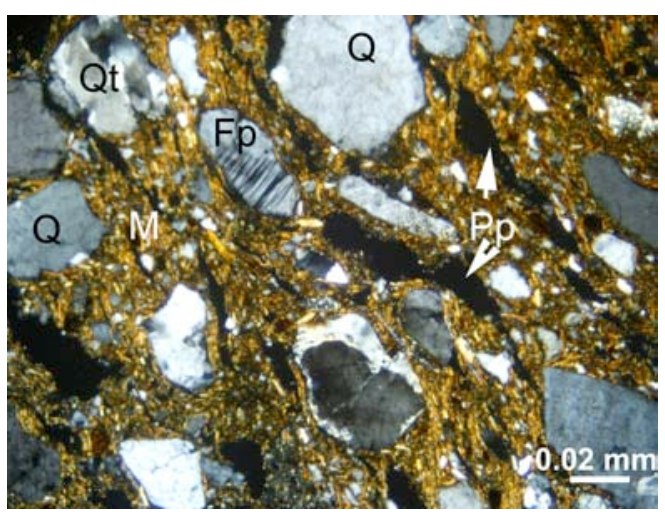

Fig. 4. Coarse ceramics, sample 270. Microcrystalline, highly birefringent matrix $(M)$ with quartzite (Qt), quartz $(Q)$, feldspar $(\mathrm{Fp})$ and primary pores $(\mathrm{Pp}) . \mathrm{N}+$ 


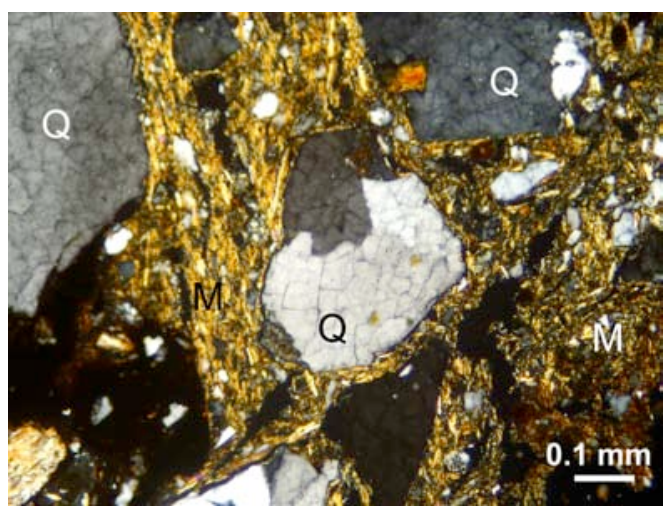

PLATE II

Fig. 5. Coarse ceramics, sample 270. Microcrystalline, highly birefringent matrix (M). Fissured quartz clasts (Q) due to the thermal shock. $N+$

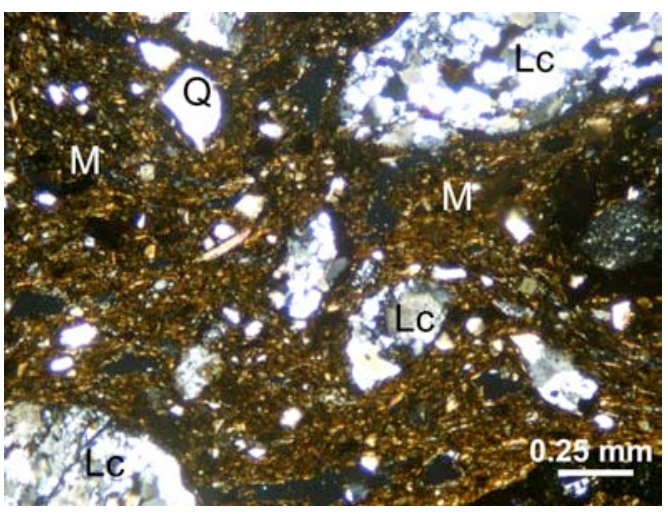

Fig. 6. Coarse ceramics, sample 271. Amorphous, almost isotropic matrix (M), and large lithoclasts (Lc) of quartzite and gneiss. Q for quartz crystalloclasts. $N+$

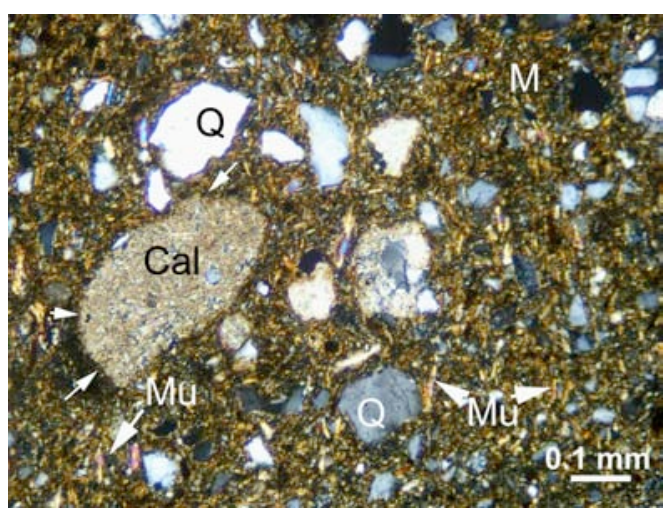

Fig. 7. Semi-fine ceramics, sample 272. Microcrystalline, anisotropic matrix (M) and clasts of quartz (Q), muscovite (Mu), limestone (Cal) and quartzite (Qt). Slight decomposition of limestone clast margins (marked by arrows). $N+$

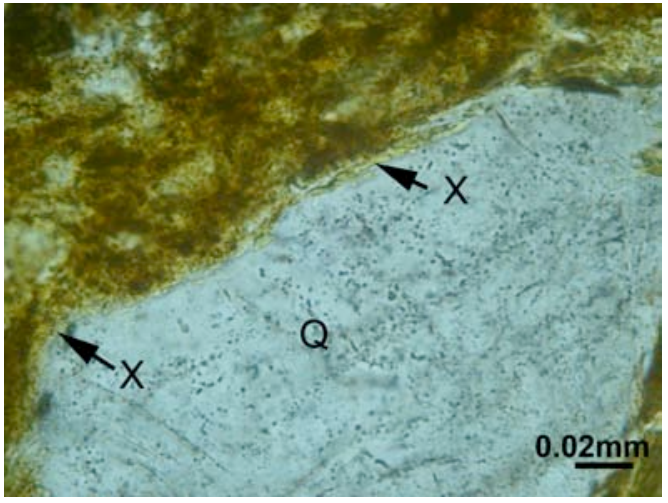

Fig. 8. Coarse ceramics, sample 270. Thermal changes reflected by a thin glass layer (marked by X) formed at the boundary between matrix (dark brown) and quartz crystal $(Q) .1 N$ 


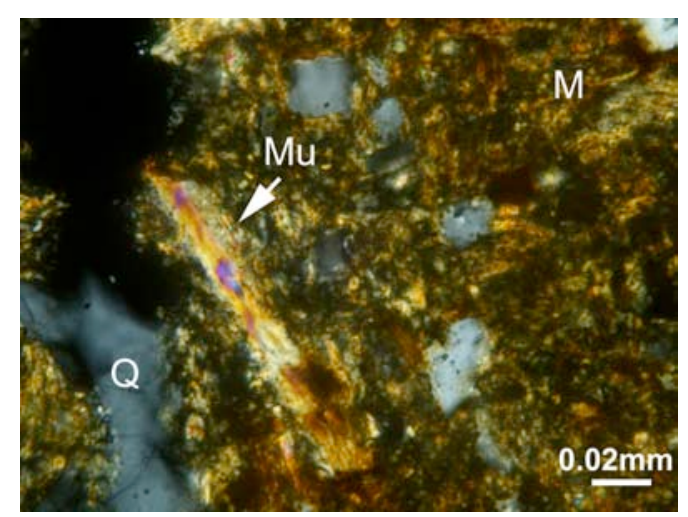

PLATE III

Fig. 9. Semi-fine ceramics, sample 272. Lamella of muscovite (Mu) partly destroyed upon firing. $M$ for matrix, $Q$ for quartz. $N+$

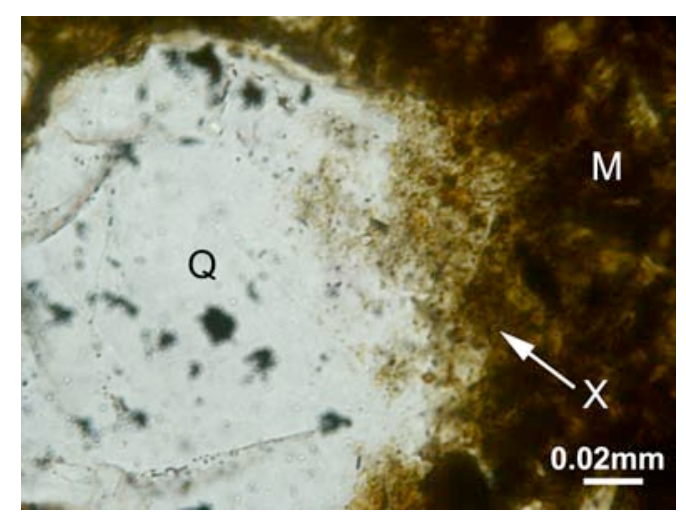

Fig. 10. Coarse ceramics, sample 271. Reaction area $(X)$ between quartz $(Q)$ and matrix $(M)$ marked by the diffusion of Fe from matrix into quartz and the scalloped rims of quartz. $1 \mathrm{~N}$ 